\title{
Prevalence and Impact of Sarcopenia in Chronic Pancreatitis: A Review of the Literature
}

\author{
Li Lian Kuan ${ }^{1,2}$ (1) • Ashley R. Dennison ${ }^{1}$ - Giuseppe Garcea ${ }^{1}$
}

Accepted: 11 October 2020/Published online: 9 November 2020

(C) The Author(s) 2020

\begin{abstract}
Introduction Malnutrition is a common sequela of chronic pancreatitis (CP). Alterations in body composition and the assessment of sarcopenia have gained the interest of clinicians in recent years. There is a scarcity of data currently available concerning sarcopenia in patients with CP. This review aims to investigate the prevalence and impact of sarcopenia in CP.

Methods Embase and Medline databases were used to identify all studies that evaluated sarcopenia and outcomes in patients with chronic pancreatitis. Due to paucity of data, conference abstracts were included. PRISMA guidelines for systematic reviews were followed.

Results Six studies, with a total of 450 individuals were reviewed. Three full-text studies and three conference abstracts met the predetermined eligibility criteria. The prevalence of sarcopenia in $\mathrm{CP}$ from all studies ranged from 17-62\%. Pancreatic exocrine insufficiency was associated as an independent and significant risk factor for sarcopenia. Sarcopenia was found to be associated with a reduced quality of life, increased hospitalisation, and reduced survival. It was associated with significantly lower islet yield following total pancreatectomy with islet auto transplantation in CP.

Conclusion The review of these existing studies amalgamates the limited data on sarcopenia and its impact on CP. It has shown that sarcopenia is exceedingly prevalent and an important risk factor in CP patients. The data presented emphasises that sarcopenia has a significant prognostic value and should be included in future prospective analyses in the outcomes of CP.
\end{abstract}

\section{Introduction}

Malnutrition is a common sequela of chronic pancreatitis (CP). Variations in body composition and the assessment of sarcopenia have gained the interest of clinicians in

Li Lian Kuan

kuan.lilian@gmail.com

1 Department of Hepatobiliary and Pancreatic Surgery, University Hospitals of Leicester NHS Trust, Gwendolen Road, Leicester LE5 4PW, UK

2 Discipline of Surgery, The Queen Elizabeth Hospital, University of Adelaide, Adelaide, SA, Australia recent years. Different body composition counterparts are being assessed in various patient populations and sarcopenia is valued as a prognostic factor of morbidity and mortality. Sarcopenia is defined by low levels of measures of muscle strength, muscle quantity/quality and physical performance as an indicator of severity [1]. Sarcopenia is correlated with an increased risk of negative consequences such as physical disability, poor quality of life and death [2-4]. There has been more awareness and interest in sarcopenia of late due to its adverse influence on outcomes [5-7]. 'Primary' sarcopenia is defined as the loss in muscle mass and muscle strength when no other cause is evident but ageing itself [2, 8]. 'Secondary' sarcopenia is defined 
as the loss of muscle mass and muscle strength that accompanies underlying chronic diseases, advanced malignancies and malnutrition [2, 9, 10]. Sarcopenia and serum albumin levels are reported to be intimately linked with pancreatic exocrine insufficiency (PEI) in patients with CP [11].

Chronic pancreatitis occurs when repeated episodes of inflammation results in the replacement of pancreatic parenchyma with fibrotic connective tissue [12-14]. The recognised hallmark of advanced CP includes atrophy and fibrosis of the pancreas, distortion of ductal anatomy, strictures, and calcifications, which can result in impairment of both endocrine and exocrine functions $[15,16]$.

The quantification of muscle attenuation in clinical practice is a developing field of interest. Current available data on the impact of sarcopenia on the prevalence and outcomes in CP are scarce with only a handful of studies reporting on sarcopenia in pancreatic ductal adenocarcinoma (PDAC). We performed a review of the literature to investigate the prevalence and the impact of sarcopenia in patients with $\mathrm{CP}$.

\section{Methods}

Medline and EMBASE databases search was performed to identify studies, which evaluated the association of sarcopenia and CP. Medical Subjects Headings (MeSH) terms used include: 'sarcopenia', 'chronic pancreatitis', 'exocrine pancreatic insufficiency', 'prevalence', 'outcomes', and 'mortality'. The search duration performed was from January 2010 to December 2019. The search was restricted to English-language studies. PRISMA guidelines for reviews were followed.

Eligibility criteria included adults over 18 years, studies detailing method of measurement of sarcopenia in CP, prevalence of sarcopenia detected in patients with $\mathrm{CP}$, and outcomes of sarcopenia in patients with CP. The outcomes included any impact on CP reported, i.e. any morbidity or mortality related. The exclusion criteria were studies that did not report on the method of measurement of sarcopenia.

All relevant studies were screened by the title and abstract. All available full text studies were assessed in detailed. The reference lists were reviewed to identify additional appropriate articles. Due to the limited number of available studies on this topic, conference abstracts were included in the review. Two researchers carried out data collection, assessed the risk of bias and analysis independently. Any disagreements were resolved through discussion between the two reviewers or further adjudication by a third reviewer. The Newcastle-Ottawa Quality Assessment Scale was used for the assessment of the quality of the studies. The primary aims of the review were to identify the prevalence and impact of sarcopenia in patients with CP.

\section{Data collection}

The data design of each study was retrieved with a predefined protocol for data extraction. The data captured included relevant information on key study characteristics, patient demographic profile, method of measuring sarcopenia, prevalence, and clinical outcomes (any). The intention was to analyse any similarities in negative outcomes between the studies, however, the heterogeneity of the findings precluded this.

\section{Results}

The search produced 25 studies, and they were identified by title and abstract. After duplicates were removed, 15 studies were screened. Nine studies did not meet the eligibility criteria and were excluded. Three full-text studies and three conference abstracts fulfilled the eligibility criteria. The PRISMA diagram (Fig. 1) outlines the selection process. Six studies, which comprised of a total population of 450 patients, were reviewed (Table 1). There were two retrospective studies [17, 18] and four [11, 19-21] prospective studies. All studies were performed in a single institution. The studies reported heterogeneous outcomes and these are reported separately below. The outcome variations may well be the reality of clinical practice, but they made comparisons difficult.

\section{Definition of CP and measurement of sarcopenia}

A diagnosis of CP was included as defined by the M-ANNHEIM classification system [22] in the study by Olesen et al. [19]. The other studies did not report how CP was assessed. Measurement of sarcopenia was performed in five studies at the level of the third lumbar vertebra (L3) using computed tomography (CT). The total cross-sectional areas of numerous muscles were quantified, which included the transversus abdominis, external and internal oblique abdominal muscles, rectus abdominis, psoas, erector spinae, and quadratus lumborum. A validated software tool was used for body composition analysis. The study by Olesen et al. measured sarcopenia with anthropometrics and bioelectric impedance (muscle mass), hand grip (muscle strength), and 'up and go' test (muscle function) [19]. The results on the measurement, prevalence, body mass index (BMI), and muscle mass index of sarcopenia in patients with chronic pancreatitis are shown in Table 2. 


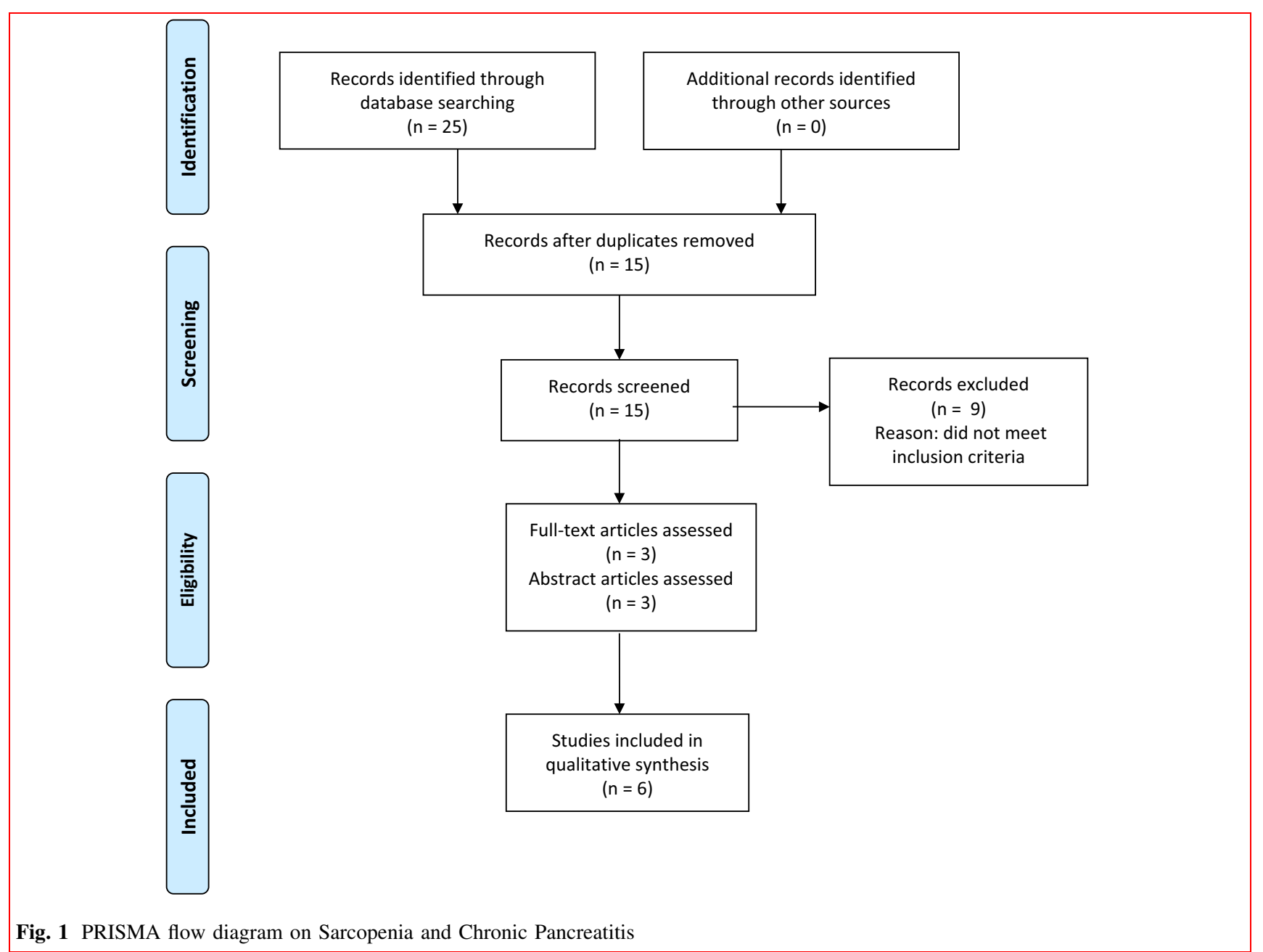

\section{Pancreatic exocrine insufficiency (PEI)}

The faecal elastase or faecal fat test was used as a measure of the exocrine pancreatic function $[19,20]$. PEI was defined as a fat excretion (aliphatic carboxylate [C14C26]) $>25 \mathrm{mmol}$ per $24 \mathrm{~h}$ or faecal elastase-1 level $<$ $200 \mathrm{mg} / \mathrm{g}$. Another alternative, ${ }^{13} \mathrm{C}$-labeled mixed triglyceride breath test was used and a percentage of ${ }^{13} \mathrm{CO}_{2}$ cumulative dose at $7 \mathrm{~h}$ below 5\% confirms PEI [11]. Two studies demonstrated PEI as a significant and independent risk factor for sarcopenia $[11,19]$. Olesen et al. demonstrated that sarcopenia has a statistically significant association with opioid treatment $(p=0.045)$ and PEI $(p=0.03)$ on multivariate analysis [19]. An association between sarcopenia and PEI $(p<0.001)$ was displayed by Shintakuya et al. [11]. It should be noted that the results from this study, included all pancreatic diseases (malignancy, neuroendocrine, and $\mathrm{CP}$ ) [11].

\section{Prevalence}

The prevalence of sarcopenia from all studies ranged from $17-62 \%$ [11, 17-21].

\section{Outcomes}

The outcomes of sarcopenia in patients with $\mathrm{CP}$ are shown in Table 3. The quality of life (QOL) was assessed using the European Organization for Research and Treatment of Cancer Quality of Life Questionnaire-C30 (EORTC QLQC30) [23]. Bieliuniene et al. demonstrated that CP patients had notably more extensive pancreatic fibrosis (PF) $(p<0.001)$ and sarcopenia decreased QOL in CP patients [20]. Olesen et al. also showed that sarcopenia was associated with reduced QOL, increased hospitalisation $(p=0.07)$, and reduced survival $(p=0.005)$ [19]. Sarcopenia was associated with significantly lower islet yield and more peri-operative blood loss $(p=0.002)$ following total pancreatectomy with islet autotransplantation in $\mathrm{CP}$ $(p=0.001)$ [21]. 
Table 1 Characteristics of studies examining the prevalence and impact of sarcopenia in chronic pancreatitis

\begin{tabular}{|c|c|c|c|c|c|c|c|}
\hline Study & Title & Year & Study type & Location & $\mathrm{CP}$ population & Mean age & $\begin{array}{l}\text { Newcastle- } \\
\text { Ottawa } \\
\text { Score\# }\end{array}$ \\
\hline $\begin{array}{l}\text { Olesen et al. } \\
\text { [19] }\end{array}$ & $\begin{array}{l}\text { Sarcopenia associates with } \\
\text { increased hospitalisation rates } \\
\text { and reduced survival in } \\
\text { patients with chronic } \\
\text { pancreatitis }\end{array}$ & 2019 & $\begin{array}{l}\text { Prospective, } \\
\text { single } \\
\text { institution }\end{array}$ & $\begin{array}{l}\text { Aalborg, } \\
\text { Denmark }\end{array}$ & 182 & $57.4 \pm 12.9$ years & 9 \\
\hline $\begin{array}{l}\text { Shintakuya } \\
\text { et al. [11] }\end{array}$ & $\begin{array}{l}\text { Sarcopenia is closely associated } \\
\text { with pancreatic exocrine } \\
\text { insufficiency in patients with } \\
\text { pancreatic disease }\end{array}$ & 2016 & $\begin{array}{l}\text { Prospective, } \\
\text { single } \\
\text { institution }\end{array}$ & $\begin{array}{l}\text { Hiroshima, } \\
\text { Japan }\end{array}$ & $\begin{array}{l}132(9 \text { with } \\
\mathrm{CP})=6.8 \%\end{array}$ & 73 years (median) & 7 \\
\hline $\begin{array}{l}\text { Bieliuniene } \\
\text { et al. [20]* }\end{array}$ & $\begin{array}{l}\text { CT- and MRI-Based Assessment } \\
\text { of Body Composition and } \\
\text { Pancreatic Fibrosis Reveals } \\
\text { High Incidence of Clinically } \\
\text { Significant Metabolic } \\
\text { Changes That Affect the } \\
\text { Quality of Life and Treatment } \\
\text { Outcomes of Patients with } \\
\text { Chronic Pancreatitis and } \\
\text { Pancreatic Cancer }\end{array}$ & 2019 & $\begin{array}{l}\text { Prospective, } \\
\text { single } \\
\text { institution }\end{array}$ & Lithuania & $\begin{array}{c}63(\mathrm{CP}) 37 \\
\quad(\mathrm{PDAC})\end{array}$ & 58 years & 6 \\
\hline $\begin{array}{l}\text { Trikudanathan, } \\
\text { et al. [21] } \\
\text { (conference } \\
\text { abstract) }\end{array}$ & $\begin{array}{l}\text { Pre-Operative Sarcopenia } \\
\text { Predicts Low Islet Cell Yield } \\
\text { Following Total } \\
\text { Pancreatectomy with Islet } \\
\text { Autotransplantation (TPIAT) } \\
\text { for Chronic Pancreatitis }\end{array}$ & 2019 & $\begin{array}{l}\text { Prospective, } \\
\text { single } \\
\text { institution }\end{array}$ & $\begin{array}{l}\text { Minneapolis, } \\
\text { United } \\
\text { States }\end{array}$ & 138 & 38 years & N/A \\
\hline $\begin{array}{l}\text { O'Connor et al. } \\
{[18]} \\
\text { (conference } \\
\text { abstract) }\end{array}$ & $\begin{array}{l}\text { Investigating the prevalence of } \\
\text { sarcopenia in chronic } \\
\text { pancreatitis in an Irish cohort: } \\
\text { A CT-scan based pilot study }\end{array}$ & 2014 & $\begin{array}{l}\text { Retrospective, } \\
\text { single } \\
\text { institution }\end{array}$ & $\begin{array}{l}\text { Dublin, } \\
\text { Ireland }\end{array}$ & 29 & 43 years (median) & N/A \\
\hline $\begin{array}{l}\text { Bulanova et al. } \\
\text { [17] } \\
\text { (conference } \\
\text { abstract) }\end{array}$ & $\begin{array}{l}\text { CT assessment of sarcopenia in } \\
\text { patients with pancreatic } \\
\text { cancer and chronic } \\
\text { pancreatitis }\end{array}$ & 2012 & $\begin{array}{l}\text { Retrospective, } \\
\text { single } \\
\text { institution }\end{array}$ & Moscow & $\begin{array}{c}29(\mathrm{CP}) 20 \\
\quad(\mathrm{PDAC})\end{array}$ & 29-63 years & N/A \\
\hline
\end{tabular}

*The study population size was 100 , which included both CP and PDAC patients

$P D A C$ Pancreatic ductal adenocarcinoma

\#NEWCASTLE-OTTAWA QUALITY ASSESSMENT SCALE

\section{Discussion}

This is a first review to examine the prevalence and impact of sarcopenia in patients with CP. In this review, sarcopenia has a prevalence of $17-64 \%$ in patients with CP. It has shown to have a statistical negative impact on various outcomes such as a lower QOL in CP patients with more than $50 \%$ pancreatic fibrosis, hospitalisation burden, mortality, and a lower islet cell yield following TPIAT.

Our findings indicate a paucity of research focusing specifically on sarcopenia and CP. We also found that there was major heterogeneity in the outcomes reported; however, the authors thought that all of the outcomes were important and had achieved statistical significance within respective studies. The included studies clearly support the hypothesis that sarcopenia negatively influence the outcomes of patients with CP. There is however limited evidence to provide a meaningful analysis in this review.

Sarcopenia is diagnosed when there is confirmation of low muscle quantity or quality; and is considered severe in addition of low muscle strength, and poor physical fitness [1]. The process of muscle tissue loss commences approximately at 40 years of age and progresses at a rate of $8 \%$ loss of muscle tissue per decade until the age of 70 , which then accelerates to $15 \%$ thereafter per decade [24]. The pathophysiology of sarcopenia is complex and is attributable to reduction in caloric consumption, denervation of muscle fibres, intracellular oxidative stress, hormonal decrease, and enhanced myostatin signalling [9]. This review has demonstrated that sarcopenia is prevalent 
Table 2 Results of studies on the measurement, prevalence, BMI, and muscle mass index of sarcopenia in patients with chronic pancreatitis

\begin{tabular}{|c|c|c|c|c|c|c|}
\hline Study & $\begin{array}{l}\text { Measurement of } \\
\text { sarcopenia }\end{array}$ & $\begin{array}{l}\text { Number or patients with } \\
\text { sarcopenia (prevalence) } \\
N(\%)\end{array}$ & $\begin{array}{l}\text { Mean BMI } \\
(\mathrm{SD}), \mathrm{kg} / \mathrm{m} 2\end{array}$ & $\begin{array}{l}\text { Sarcopenia } \\
(\mathrm{BMI}<18)\end{array}$ & $\begin{array}{l}\text { Sarcopenia } \\
(\mathrm{BMI}>25)\end{array}$ & $\begin{array}{l}\text { Median L3 muscle } \\
\text { mass index }(\mathrm{cm} 2 / \mathrm{m} 2)\end{array}$ \\
\hline $\begin{array}{l}\text { Olesen et al. } \\
\text { [19] }\end{array}$ & $\begin{array}{l}\text { Anthropometrics } \\
\text { Bioelectric impedance, } \\
\text { Hand grip, } \\
\text { Up and go test }\end{array}$ & $31(17.0 \%)$ & $20.9 \pm 4.1$ & 8 & - & - \\
\hline $\begin{array}{l}\text { Shintakuya } \\
\text { et al. [11] }\end{array}$ & $\begin{array}{l}\mathrm{CT} \text { axial images at } \mathrm{L} 3 \\
\text { vertebral }\end{array}$ & $37(15 \%)$ & - & - & - & $\begin{array}{l}43.51 \text { (male) } 36.26 \\
\quad \text { (female) }\end{array}$ \\
\hline $\begin{array}{l}\text { Bieliuniene } \\
\text { et al. [20] }\end{array}$ & $\begin{array}{l}\mathrm{CT} \text { axial images at } \mathrm{L} 3 \\
\text { vertebral }\end{array}$ & $\begin{array}{l}21 \text { out of } 63 \text { patients } \\
(33.3 \%)\end{array}$ & $24.08 \pm 4.5$ & $\begin{array}{l}6 / 21 \\
\quad(29 \%)\end{array}$ & $3 / 21(14 \%)$ & $\begin{array}{l}49.60 \pm 7.5 \\
\quad(\text { men }) 47.00 \pm 8.6 \\
\quad(\text { women })\end{array}$ \\
\hline $\begin{array}{l}\text { Trikudanathan } \\
\text { et al. [21] }\end{array}$ & $\begin{array}{l}\text { CT axial images at L3 } \\
\text { vertebral }\end{array}$ & $\begin{array}{l}46 \text { out of } 138 \text { patients } \\
(33.3 \%)\end{array}$ & - & - & - & - \\
\hline $\begin{array}{l}\text { O'Connor } \\
\text { et al. [18] }\end{array}$ & $\begin{array}{l}\text { CT axial images at } \mathrm{L} 3 \\
\text { vertebral }\end{array}$ & 15 out of 29 patients $(52 \%)$ & 25.6 & 6 & 7 & - \\
\hline $\begin{array}{l}\text { Bulanova } \\
\text { et al. [17] }\end{array}$ & $\begin{array}{l}\mathrm{CT} \text { axial images at L3 } \\
\text { vertebral }\end{array}$ & $18(62 \%)$ & $22.16 \pm 2.3$ & $3 / 18$ & $2 / 18$ & - \\
\hline
\end{tabular}

in patients with $\mathrm{CP}$ and may be present in underweight, normal weight and obese patients. It is important to diagnose sarcopenia regardless of the BMI, as the presence of sarcopenia did not correlate with BMI values. Individuals of similar BMI display different percentages of lean and adipose tissue [25, 26]. Sarcopenic obesity is defined as a reduction in lean body mass in the context of excess fat [27], and it is easily overlooked in obese patients. Individuals who are obese and sarcopenic have worse outcomes than those who are sarcopenic and non-obese [28]. Olesen et al. reported that $23(74 \%)$ of sarcopenic patients had a normal or obese BMI and demonstrated a significant association between sarcopenia and BMI subgroups $(p=0.009)$ [19].

The specificity and precision of body composition measurement modalities offer a new perspective to view the body habitus. Each has its own pros and cons in assessing changes in muscle or adipose tissue distribution. They provide a robust assessment for sarcopenia which is simple, feasible, and help facilitate development of comprehensive approaches to decision-making regarding perioperative care [29]. Conventional anthropometric parameters have a low index in detecting sarcopenia; however, it is not an accurate assessment of muscle tissue [30].

Conventional nutritional assessments also do not accurately detect sarcopenia, and radiology has been proven to be more reliable [31]. The utilisation of radiology in the examination of body composition is highly differentiated, with the technology to recognise and discriminate between muscle, fat, as well as the distribution of adiposity within intermuscular, subcutaneous, and visceral sites [25]. Dualenergy X-ray absorptiometry (DXA) is feasible, accurate, non-invasive, inexpensive, and regarded as the ideal standard for quantifying muscle mass [32]. However, the gold standards for non-invasive measurement of muscle mass are magnetic resonance imaging (MRI) and CT [33]. The evaluation of sarcopenic obesity using CT data was introduced in 2013 [34], and is an objective and precise assessment of sarcopenia. The cut-off points for the diagnosis of sarcopenia are arbitrary at this time; however, Prado et al. defined sarcopenia cut-offs at approximately $52.4 \mathrm{~cm}^{2} / \mathrm{m}^{2}$ for men and $38.5 \mathrm{~cm}^{2} / \mathrm{m}^{2}$ for women [25]. The use of imaging to evaluate sarcopenia however does not assess the aspect of functional muscle status.

An alternative of measurement of body muscle/fat composition is a hand-held bioelectric impedance analysis (BIA) machine that is affordable, widely available, and portable. It procures an evaluation of muscle mass based on whole-body electrical conductivity [1]. In non-obese adults, an accurate two-compartment (lean, fat) measurement of body composition can be made in 10 min with a BIA machine [35]. The studies in this review used CT imaging to detect sarcopenia and only one study used anthropometric measures. It should be noted, however, that sarcopenia is a relatively subjective measurement.

It is worth mentioning the impact of sarcopenia in pancreatic ductal adenocarcinoma (PDAC). Bieliuniene et al. included patients with PDAC and reported that a substantial number of cases of sarcopenia were detected in patients with CP (62\%), demonstrating that sarcopenia was more prevalent in chronic diseases in contrast to malignancy [20]. Shintakuya et al. took into account all pancreatic diseases (malignancy, neuroendocrine, and $\mathrm{CP}$ ) [11]. Although they were analyzed separately in subgroups, this is a potential confounding variable. Recent metaanalyses have shown sarcopenia (HR 1.49; 95\% CI 
Table 3 Results on the impact of sarcopenia in chronic pancreatitis

\begin{tabular}{|c|c|c|c|c|}
\hline Study & Impact of Sarcopenia in $\mathrm{CP}$ & Hospitalisation & Mortality & Quality of life (QoL) \\
\hline $\begin{array}{l}\text { Olesen et al. } \\
\text { [19] }\end{array}$ & $\begin{array}{l}\text { PEI was an independent risk factor for } \\
\text { sarcopenia }(p=0.03) \text {. Sarcopenia was } \\
\text { significantly associated with opioid } \\
\text { treatment }(p=0.045) \text { and PEI } \\
(p=0.03) \text { on multivariate analysis }\end{array}$ & $\begin{array}{l}\text { Increased risk of hospitalisation } \\
(p=0.07) \text {, increased number of in- } \\
\text { hospital days }(p<0.001) \text {. Sarcopenia } \\
\text { was not associated with an increased } \\
\text { risk of pancreatitis related } \\
\text { hospitalisation during the follow-up } \\
\text { period }(p=0.39)\end{array}$ & $\begin{array}{l}\text { Reduced } \\
\quad \text { survival } \\
\quad(p=0.005)\end{array}$ & $\begin{array}{l}\text { Decreased median } \\
\text { (IQR) global } \\
\text { health scores } \\
(p=0.003)\end{array}$ \\
\hline $\begin{array}{l}\text { Shintakuya } \\
\text { et al. [11] }\end{array}$ & $\begin{array}{l}\text { Sarcopenia was associated with PEI in } \\
\text { men }(P<0.001) \text { and women } \\
(P=0.012) \text { on univariate analyses. } \\
\text { Only sarcopenia remained } \\
\text { independently associated with PEI } \\
(P<0.001) \text { on multivariate } \\
\text { analysis.**takes into accounts all } \\
\text { pancreatic diseases (malignancy, } \\
\text { neuroendocrine, and CP) }\end{array}$ & N/A & N/A & N/A \\
\hline $\begin{array}{l}\text { Bieliuniene } \\
\text { et al. [20] }\end{array}$ & $\begin{array}{l}\text { There was no significant difference in } \\
\text { sarcopenia status among patients with } \\
\text { CP and PDAC }(p=0.85) \text {. The } \\
\text { presence of osteopenia/osteoporosis } \\
\text { predicts the presence of sarcopenia } \\
(p=0.02) \text {. Patients with CP had more } \\
\text { pronounced pancreatic fibrosis }(\mathrm{PF}) \\
(p<0.001) * * \text { takes into accounts } \\
\text { pancreatic malignancy }\end{array}$ & N/A & N/A & $\begin{array}{l}\text { Lower QOL in } \\
\text { patients with } \\
\mathrm{PF} \geq 50 \% \text { and in } \\
\text { the } \mathrm{CP} \text { group. } \\
(p<0.001)\end{array}$ \\
\hline $\begin{array}{l}\text { Trikudanathan } \\
\text { et al. [21] }\end{array}$ & $\begin{array}{l}\text { Peri-operative blood loss was more } \\
\text { common in sarcopenic patients as } \\
\text { compared to non-sarcopenic patients } \\
(p=0.002) \text {. Sarcopenia was associated } \\
\text { with significantly lower islet yield } \\
\text { following TPIAT }(p=0.001) \text {. }\end{array}$ & N/A & N/A & N/A \\
\hline $\begin{array}{l}\text { O'Connor } \\
\text { et al. [18] }\end{array}$ & $\begin{array}{l}\text { This preliminary study has shown a high } \\
\text { prevalence of sarcopenia in } \mathrm{CP} \\
\text { independent of BMI }\end{array}$ & N/A & N/A & N/A \\
\hline $\begin{array}{l}\text { Bulanova } \\
\text { et al. [17] }\end{array}$ & $\begin{array}{l}\text { Sarcopenia is highly prevalent in patients } \\
\text { with pancreatic cancer and CP }(66 \%) \\
\text { and may be present in patients with any } \\
\text { BMI values }\end{array}$ & N/A & N/A & N/A \\
\hline
\end{tabular}

1.27-1.74, $p<0.001$ ) and sarcopenic obesity (HR 2.01; 95\%CI $1.55-2.61, p<0.001)$ are significantly associated with worse overall survival in patients with PDAC [36]. A study has shown that sarcopenia is a strong predictor of the occurrence of pancreatic fistula and survival after pancreatoduodenectomy and recommends reconditioning of the sarcopenia prior to the operation [37].

Patients with $\mathrm{CP}$ potentially have a more pronounced level of malnutrition. Various factors such as intractable pain, alcoholism, malabsorption, and maldigestion from PEI, renders these patients at a considerable risk for sarcopenia. Patients with $\mathrm{CP}$ are likely to have more co-morbidities which may contribute to the loss of muscle mass and more adverse outcomes. CP was not properly defined except for one study which used the
M-Anheim assessment [19]. Nutritional assessment and the complications of $\mathrm{CP}$ are pivotal in the management of these patients. Approximately $30 \%-50 \%$ of $\mathrm{CP}$ patients have increment of resting energy expenditure [38]. The key strategy in these patients is the early detection of sarcopenia and active interventions. The management involves a multidisciplinary team and includes alcohol abstinence, pain management, nutritional and dietary improvement, and pancreatic enzyme supplementation [39].

At this point in time, there is no evidence to suggest that sarcopenia can be treated or is modifiable. There is insufficient evidence available to guide the treatment of sarcopenia. In a complex disease like CP, an optimal body habitus is unlikely to be achievable in the short term. 
Nevertheless, the prognostic value of sarcopenia can be a valuable adjunct. Persons with sarcopenic obesity were evaluated with various exercise interventions (aerobic, resistance, and combined), and it was discovered that those in the resistance group showed the most improvements in strength [40]. The very first randomised controlled trial (RCT) is currently under study by the Japanese which evaluates the clinical influence of exercise therapy on sarcopenia in CP patients [41]. We await the results with anticipation.

Despite the relevant findings, this review has a few limitations. First, due to the paucity of data, conference abstracts were included to provide a more robust data for the review. The studies analysed were retrospective and prospective cohorts, and consisted of heterogeneous patient populations hence selection bias may be a limitation. All studies were single-centred, and consisted of a small patient population hence within each study, analysis remains a potential limitation. The large range of prevalence of sarcopenia reported across the studies may be due to how it was measured (large vs small population) and the duration the patients had been diagnosed with $\mathrm{CP}$ before they entered into the study.

Nevertheless, this review provides a platform to expand on this important prognostic factor. An increased effort is required to address the deficiency of research on this topic as evident in Table 3. Future studies should be designed to analyse the relevance of sarcopenia on the prognosis and management of $\mathrm{CP}$ patients by investigating the negative clinical outcomes. In addition, there is also a need for serial assessments of patients prospectively while attempting to treat their sarcopenia.

\section{Conclusion}

The review of these existing studies amalgamates the paucity of data on sarcopenia and its impact on CP. It has shown that sarcopenia is exceedingly prevalent and an important risk factor in $\mathrm{CP}$ patients. The data presented emphasises that sarcopenia has a significant prognostic value and should be included in future prospective analyses on the outcomes of CP. There is a crucial need for more studies to address the deficiency of research on this topic and further elucidate the impact of sarcopenia in patients with CP.

\section{Compliance with ethical standards}

Conflict of interest The authors declare that they have no conflict of interest.
Open Access This article is licensed under a Creative Commons Attribution 4.0 International License, which permits use, sharing, adaptation, distribution and reproduction in any medium or format, as long as you give appropriate credit to the original author(s) and the source, provide a link to the Creative Commons licence, and indicate if changes were made. The images or other third party material in this article are included in the article's Creative Commons licence, unless indicated otherwise in a credit line to the material. If material is not included in the article's Creative Commons licence and your intended use is not permitted by statutory regulation or exceeds the permitted use, you will need to obtain permission directly from the copyright holder. To view a copy of this licence, visit http://creativecommons. org/licenses/by/4.0/.

\section{References}

1. Cruz-Jentoft AJ, Bahat $\mathrm{G}$, Bauer $\mathrm{J}$, Boirie $\mathrm{Y}$, Bruyère $\mathrm{O}$, Cederholm $\mathrm{T}$ et al (2019) Sarcopenia: revised European consensus on definition and diagnosis. Age Ageing 48(1):16-31

2. Cruz-Jentoft AJ, Baeyens JP, Bauer JM, Boirie Y, Cederholm T, Landi $F$ et al (2010) Sarcopenia: European consensus on definition and diagnosis. Age Ageing 39(4):412-423

3. Delmonico MJ, Harris TB, Lee JS, Visser M, Nevitt M, Kritchevsky SB et al (2007) Alternative definitions of sarcopenia, lower extremity performance, and functional impairment with aging in older men and women. J Am Geriatr Soc 55(5):769-774

4. Goodpaster BH, Park SW, Harris TB, Kritchevsky SB, Nevitt M, Schwartz AV et al (2006) The loss of skeletal muscle strength, mass, and quality in older adults: The Health, aging and body composition study. J Gerontol Ser A Biol Sci Med Sci 61(10):1059-1064

5. Sinclair M, Gow PJ, Grossmann M, Angus PW (2016) Review article: sarcopenia in cirrhosis-aetiology, implications and potential therapeutic interventions. Aliment Pharmacol Ther 43(7):765-777

6. Hanai T, Shiraki M, Nishimura K, Ohnishi S, Imai K, Suetsugu A et al (2015) Sarcopenia impairs prognosis of patients with liver cirrhosis. Nutrition 31(1):193-199

7. Nishikawa H, Shiraki M, Hiramatsu A, Moriya K, Hino K, Nishiguchi S (2016) Japan Society of hepatology guidelines for sarcopenia in liver disease: recommendation from the working group for creation of sarcopenia assessment criteria. Hepatol Res 46(10):951-963. https://doi.org/10.1111/hepr.12774

8. Tieland M, Trouwborst I, Clark BC (2018) Skeletal muscle performance and ageing. J Cachexia Sarcopenia Muscle 9(1):3-19. https://doi.org/10.1002/jcsm.12238

9. Marty E, Liu Y, Samuel A, Or O, Lane J (2017) A review of sarcopenia: Enhancing awareness of an increasingly prevalent disease. Bone 105:276-286

10. Nishikawa H, Enomoto H, Ishii A, Iwata Y, Miyamoto Y, Ishii N et al (2017) Elevated serum myostatin level is associated with worse survival in patients with liver cirrhosis. J Cachexia Sarcopenia Muscle 8(6):915-25. https://doi.org/10.1002/jcsm.12212

11. Shintakuya R, Uemura K, Murakami Y, Kondo N, Nakagawa N, Urabe K, Sueda T (2017) Sarcopenia is closely associated with pancreatic exocrine insufficiency in patients with pancreatic disease. Pancreatology 17(1):70-75. https://doi.org/10.1016/j. pan.2016.10.005

12. Gress TM, Müller-Pillasch F, Lerch MM, Friess H, Büchler M, Beger HG, et al (1994) Balance of expression of genes coding for extracellular matrix proteins and extracellular matrix degrading proteases in chronic pancreatitis. Z Gastroenterol, 32(4):221-5. Available from: https://www.ncbi.nlm.nih.gov/pubmed/8017097 
13. Mayerle J, Hoffmeister A, Witt H, Lerch MM, Mössner J (2013) Chronic Pancreatitis. Dtsch Aerzteblatt Online, 110(22):387. Available from: https://www.aerzteblatt.de/10.3238/arztebl.2013. 0387

14. Majumder S, Chari ST (2016) Chronic pancreatitis. Lancet 387(10031):1957-1966

15. Kirkegård J, Mortensen FV, Cronin-Fenton D (2017) Chronic pancreatitis and pancreatic cancer risk: a systematic review and meta-analysis. Am J Gastroenterol 112(9):1366-1372 Available from: https://insights.ovid.com/crossref?an=00000434-201709 000-00008

16. Whitcomb DC, Frulloni L, Garg P, Greer JB, Schneider A, Yadav D et al (2016) Chronic pancreatitis: An international draft consensus proposal for a new mechanistic definition. Pancreatology 16(2):218-224

17. Bulanova E, Lyadov VK, Mershina EA, Sinitsyn V, Moscow/Ru (2012) CT assessment of sarcopenia in patients with pancreatic cancer and chronic pancreatitis. https://doi.org/10.1594/ecr2012/ B-0563

18. OConnor D, Kok T, Purcell C, Duggan S, Conlon K (2014) Investigating the prevalence of sarcopenia in chronic pancreatitis in an irish cohort: a CT-scan based pilot study. Pancreatology 14(3):S74

19. Olesen SS, Büyükuslu A, Køhler M, Rasmussen HH, Drewes AM (2019) Sarcopenia associates with increased hospitalization rates and reduced survival in patients with chronic pancreatitis. Pancreatology 19(2):245-251

20. Bieliuniene E, Frøkjær JB, Pockevicius A, Kemesiene J, Lukosevičius S, Basevicius A et al (2019) CT-and MRI-based assessment of body composition and pancreatic fibrosis reveals high incidence of clinically significant metabolic changes that affect the quality of life and treatment outcomes of patients with chronic pancreatitis and pancreatic cancer. Med 55(10):649

21. Trikudanathan G, Feussom G, Teigen L, Munigala S, Price K, Dirweesh A, Beilman G (2020) Pre-operative sarcopenia predicts low islet cell yield following total pancreatectomy with islet autotransplantation (TPIAT) for chronic pancreatitis (CP). Gastroenterology 24(10):2423-2430

22. Schneider A, Löhr JM, Singer MV (2007) The M-ANNHEIM classification of chronic pancreatitis: Introduction of a unifying classification system based on a review of previous classifications of the disease. J Gastroenterol 42(2):101-119

23. Fitzsimmons D, Kahl S, Butturini G, Van Wyk M, Bornman P, Bassi C, Johnson CD (2005) Symptoms and quality of life in chronic pancreatitis assessed by structured interview and the EORTC QLQ-C30 and QLQ-PAN26. Am J Gastroenterol 100(4):918-926

24. Grimby G, Saltin B (1983) The ageing muscle. Clin Physiol 3(3):209-18. https://doi.org/10.1111/j.1475-097X.1983. tb00704.x

25. Prado CM, Lieffers JR, McCargar LJ, Reiman T, Sawyer MB, Martin L et al (2008) Prevalence and clinical implications of sarcopenic obesity in patients with solid tumours of the respiratory and gastrointestinal tracts: a population-based study. Lancet Oncol 9(7):629-635. https://doi.org/10.1016/S1470-2045(08) 70153-0

26. Baracos VE, Arribas L, Baracos VE. Sarcopenic obesity: Hidden muscle wasting and its impact for survival and complications of cancer therapy. Available from: https://academic.oup.com/ annonc/article-abstract/29/suppl_2/ii1/4913824
27. Prado CMM, Wells JCK, Smith SR, Stephan BCM, Siervo M (2012) Sarcopenic obesity: a Critical appraisal of the current evidence. Clin Nutr 31:583-601

28. Morley JE, Baumgartner RN, Roubenoff R, Mayer J, Nair KS (2001) Sarcopenia. J Lab Clin Med 137(4):231-243

29. Takagi K, Yagi T, Yoshida R, Umeda Y, Nobuoka D, Kuise T et al (2017) Sarcopenia predicts postoperative infection in patients undergoing hepato-biliary-pancreatic surgery. Int J Surg Open 1(6):12-18

30. Tosato M, Marzetti E, Cesari M, Savera G, Miller RR, Bernabei $R$ et al (2017) Measurement of muscle mass in sarcopenia: from imaging to biochemical markers. Aging Clin Exp Res 29(1):19-27

31. Lou N, Chi CH, Chen XD, Zhou CJ, Wang SL, Zhuang CL et al (2017) Sarcopenia in overweight and obese patients is a predictive factor for postoperative complication in gastric cancer: a prospective study. Eur J Surg Oncol 43(1):188-195

32. Buckinx F, Landi F, Cesari M, Fielding RA, Visser M, Engelke K et al (2018) Pitfalls in the measurement of muscle mass: a need for a reference standard. J Cachexia Sarcopenia Muscle $9(2): 269-278$

33. Beaudart C, McCloskey E, Bruyère $\mathrm{O}$, Cesari $\mathrm{M}$, Rolland $\mathrm{Y}$, Rizzoli R et al (2016) Sarcopenia in daily practice: assessment and management. BMC Geriatr 16(1):1-10

34. Martin L, Birdsell L, MacDonald N, Reiman T, Clandinin MT, McCargar LJ et al (2013) Cancer cachexia in the age of obesity: skeletal muscle depletion is a powerful prognostic factor, independent of body mass index. J Clin Oncol 31(12):1539-1547

35. Ghosh S, Meister D, Cowen S, Hannan WJ, Ferguson A (1997) Body composition at the bedside. Eur J Gastroenterol Hepatol 9(8):783-788

36. Mintziras I, Miligkos M, Waechter S, Manoharan J, Maurer E, Bartsch DK (2018) Sarcopenia and sarcopenic obesity are significantly associated with poorer overall survival in patients with pancreatic cancer: systematic review and meta-analysis. Int $\mathbf{J}$ Surg 59:19-26

37. Vitali GC, Ronot M, Assalino M, Andres A, Terraz S, Puppa G, et al (2016) Sarcopenia is a predictor of pancreatic fistula occurence after duodenopancreatectomy. HPB 18:e385. https:// doi.org/10.1016/j.hpb.2016.03.005

38. Hébuterne X, Hastier P, Péroux JL, Zeboudj N, Delmont JP, Rampal P (1996) Resting energy expenditure in patients with alcoholic chronic pancreatitis. Dig Dis Sci 41(3):533-539

39. Rasmussen HH, Irtun $\varnothing$, Olesen SS, Drewes AM, Holst M (2013) Nutrition in chronic pancreatitis. World $\mathrm{J}$ Gastroenterol 19(42):7267-7275

40. Chen HT, Chung YC, Chen YJ, Ho SY, Wu HJ (2017) Effects of different types of exercise on body composition, muscle strength, and IGF-1 in the elderly with sarcopenic obesity. J Am Geriatr Soc 65(4):827-832

41. Yoh K, Nishikawa H, Enomoto H, Iwata Y, Ishii A, Yuri Y, Takata R (2018) Clinical influence of exercise therapy on sarcopenia in patients with chronic pancreatitis: a study protocol for a randomised controlled trial. BMJ open gastroenterol 5(1):e000193

Publisher's Note Springer Nature remains neutral with regard to jurisdictional claims in published maps and institutional affiliations. 